\title{
DECREASING PREVALENCE OF THE ACUTE/SUBACUTE CLINICAL FORM OF PARACOCCIDIOIDOMYCOSIS IN MATO GROSSO DO SUL STATE, BRAZIL
}

\author{
Larissa Rodrigues FABRIS(1), Úrsulla Vilella ANDRADE(1), Aline FERREIRA DOS SANTOS(1), Ana Paula da Costa MARQUES(2), \\ Sandra Maria do Valle Leone de OLIVEIRA(1), Rinaldo Pôncio MENDES(3) \& Anamaria Mello Miranda PANIAGO(1)
}

\begin{abstract}
SUMMARY
With the objective to evaluate the behavior of paracoccidioidomycosis in the last three decades, clinical and epidemiological data of 595 patients admitted to clinical services of the Federal University of Mato Grosso do Sul from 1980 to 2009 were investigated. Gender, age distribution, clinical form, comorbidity with tuberculosis or AIDS, and mortality were compared by decades of clinical admission. It was shown that during the three decades there was a decrease in women percentage, and the same manner occurred a reduction in participants in the age group of 20 to 39 years. Moreover, the acute/subacute forms have been diminished in the period. These fluctuations are closely related and can be simultaneously analyzed. Increased AIDS co-infection prevalence from the first to the second decade was also revealed, coinciding with the appearance of the retroviral epidemic and stabilizing during the third decade. No change in the tuberculosis co-infection rate was observed (overall $=6.9 \%$ ). It reinforces the importance of this co-morbidity. The overall mortality rate remained steady at $6.7 \%$, not varying significantly from one decade to another. The persistent mortality rate calls attention to the importance of this neglected disease.
\end{abstract}

KEYWORDS: Paracoccidioidomycosis; Geographic area; Age group.

\section{INTRODUCTION}

Paracoccidioidomycosis (PCM) is a systemic mycosis caused by the thermal dimorphic fungus Paracoccidioides brasiliensis and is endemic in Latin America. Brazil presents the highest number of PCM cases of the Latin countries, with PCM predominantly occurring in the southern, southeastern and midwestern regions of Brazil ${ }^{6,12,24}$.

Infection occurs through the inhalation of conidia and mycelia fragments from the soil and is predominant in rural workers. Once inhaled, the conidia advance to the pulmonary alveoli, where they settle, advance into the yeast phase and constitute the primary complex. Thereafter, lymphohematogenous dissemination can spread the fungi to any site in the organism. Individuals with appropriate cell mediated immunity show regression of these foci; however, viable fungi can remain in a latent stage, which can reactivate causing a disease with the chronic form. Individuals with compromised cellular immunity can develop the disease immediately after the infection, usually presented as the acute/subacute form ${ }^{14}$.

PCM demonstrates some puzzling regional differences, such as the rarity of acute/subacute cases in Uruguay ${ }^{11}$, Paraguay ${ }^{28}$ and Argentina ${ }^{15}$. In Brazil, the prevalence of the acute/subacute clinical form varies by state and region as well, being rare in Rio Grande do Sul ${ }^{10}$ and more frequent in the states of Maranhão ${ }^{20,38}$, Pará $^{13}$, Minas Gerais ${ }^{23}$, São Paulo ${ }^{6}$, Mato Grosso do $\mathrm{Sul}^{24}$, and Rio de Janeiro ${ }^{37}$.

However, as transversal analyses of PCM in the region are scarce, this study was proposed to verify if modifications in the behavior of PCM have occurred over the past three decades in the endemic area of Mato Grosso do Sul.

\section{PATIENTS AND METHODS}

Study design. Case series observational epidemiological study.

Location and study period. Research was conducted at the Department of Infectious and Parasitic Diseases (IPD) at the Federal University of Mato Grosso do Sul University Hospital (NHU-UFMS), located in Campo Grande - MS. Data for this study were collected as part of systemic mycoses clinical services and included cases treated from 1980 to 2009.

Study participants. All cases of paracoccidioidomycosis confirmed by identification of the etiologic agent by direct mycological examination, culture or histopathology from clinical specimens were included in this study.

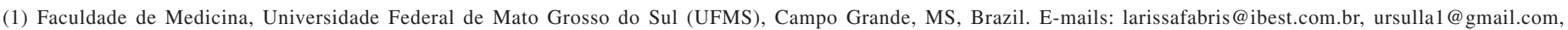
alineafds@yahoo.com.br, sandrinhaleone@gmail.com, anapaniago@yahoo.com.br

(2) Centro de Ciências Biológicas e da Saúde, Universidade Federal de Mato Grosso do Sul, Campo Grande (UFMS), MS, Brazil. E-mail: apcmarques@ @otmail.com

(3) Faculdade de Medicina, Universidade Estadual Paulista (UNESP), Botucatu, SP, Brazil. E-mail: tietemendes@terra.com.br

Correspondence to: Anamaria Mello Miranda Paniago. E- mail: anapaniago@yahoo.com.br 


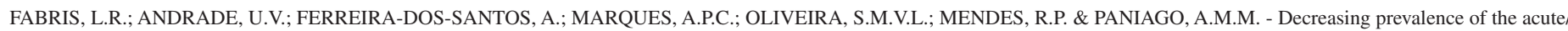
subacute clinical form of paracoccidioidomycosis in Mato Grosso do Sul State, Brazil. Rev. Inst. Med. Trop. Sao Paulo, 56(2): 121-5, 2014.

Data collection. The clinical and epidemiological data of patients admitted between 1980 and 1998 were obtained by retrospective analysis of medical records. From 1999 onwards, the study became prospective and utilized a collection protocol developed for this purpose. Patients were divided into three groups according to decade of diagnosis: 1980 to 1989,1990 to 1999 and 2000 to 2009 .

Classification of clinical forms and outcomes. Patients were classified by acute/subacute or chronic clinical form according to specifications set forth by MENDES ${ }^{21}$.

Cure was defined as the disappearance of the clinical manifestations previously presented by every patient, associated with disappearance of the pulmonary lesions of active disease on chest radiography or its substitution by fibrotic scars, normalization of the erythrocyte sedimentation rate (or C-reactive protein serum levels), and a regression to negative of the antibody serum levels determined by the double agar gel immunodiffusion test, independently of casual relapse and re-treatment.

Deaths were considered only those occurring in patients with active disease clinically attributable to paracoccidioidomycosis and/or confirmed by postmortem examination.

Statistical analysis. Comparison of frequencies was performed by chi-square test or Fisher's exact test. When three groups were compared, analysis was completed with the Goodman test. Continuous variables were presented as mean and standard deviation. The comparison between two means was performed by Student's t test. Statistical analyses were performed using SAS version 9.2 (SAS Institute, Cary, North Carolina). Differences were considered significant when $\boldsymbol{p} \leq 0.05$.

Ethical considerations. The project was approved by the Federal University of Mato Grosso do Sul Ethics Committee on Human Research, under protocol No. 1620 on March $4^{\text {th }}, 2010$.

\section{RESULTS}

During the study period, 595 patients ranging in age from four to 94 years $(45.2 \pm 14.2)$ were included and $549(92.3 \%)$ of these patients were male. Of these patients, $73(12.3 \%)$ presented the juvenile form. Association with HIV was observed in $16(2.7 \%)$ patients and association with tuberculosis was found in $41(6.9 \%)$ patients. There were $40(6.7 \%)$ deaths among the 595 patients evaluated during the period from 1980 to 2009 .

The first decade (1980 - 1989) revealed a higher prevalence of female patients and a lower prevalence of male patients than in the third decade (2000 - 2009), as shown in Table 1. The prevalence of patients up to 39 years of age was lower in the third decade (2000 - 2009) than in the other two decades; however, patients aged 40 to 59 years old were more prevalent in the third decade $(2000$ - 2009) than in the other two decades (Table 1). The first decade (1980 - 1989) showed a higher prevalence of acute/subacute cases and a lower prevalence of chronic cases than in other decades (Table 1). Finally, coinfection with HIV increased with time, but remained stable for the last two decades, whereas coinfection with tuberculosis remained stable throughout the three decades (Table 1).

The average age increased from the first to the third decade of study: $41.8 \pm 15.1$ years in the first decade, $45.0 \pm 13.3$ years in the second decade and $49.5 \pm 13.1$ years in the third decade $(p<0.01)$.

Mortality remained stable throughout the three decades and showed no difference in clinical form, except a tendency for more acute-subacute cases than chronic cases in the second decade $(\boldsymbol{p}=0.062)$, as shown in Table 2 .

Regarding treatment, cotrimoxazole was taken by $90.3 \%$ of patients

Table 1

Distribution of 595 paracoccidioidomycosis patients by period of admission at the Infectious and Parasitic Diseases - University Hospital of the Universidade Federal do Mato Grosso do Sul, and clinical and epidemiological (demographic) findings

\begin{tabular}{|c|c|c|c|c|c|c|c|}
\hline & \multicolumn{2}{|c|}{$\begin{array}{c}1980-1989 \\
n=206\end{array}$} & \multicolumn{2}{|c|}{$\begin{array}{c}1990-1999 \\
n=216\end{array}$} & \multicolumn{2}{|c|}{$\begin{array}{c}2000-2009 \\
n=173\end{array}$} & \multirow[t]{2}{*}{$p$ value } \\
\hline & $\mathrm{N}$ & $\%$ & $\mathrm{~N}$ & $\%$ & $\mathrm{~N}$ & $\%$ & \\
\hline Gender & & & & & & & $<0.03$ \\
\hline Female & 24 & 11.7 & 14 & 6.5 & 8 & 4.6 & \\
\hline Male & 182 & 88.3 & 202 & 93.5 & 165 & 95.4 & \\
\hline Age group (years) & & & & & & & $<0.01$ \\
\hline $0-19$ & 18 & 8.7 & 12 & 5.6 & 4 & 2.3 & \\
\hline 20-39 & 69 & 33.5 & 62 & 28.7 & 27 & 15.6 & \\
\hline $40-59$ & 91 & 44.2 & 112 & 51.9 & 108 & 62.4 & \\
\hline$\geq 60$ & 28 & 13.6 & 30 & 13.9 & 34 & 19.7 & \\
\hline Clinical Form & & & & & & & $<0.01$ \\
\hline Acute/Subacute & 44 & 21.4 & 21 & 9.7 & 8 & 4.6 & \\
\hline Chronic & 162 & 78.6 & 195 & 90.3 & 165 & 95.4 & \\
\hline HIV co-infection & 0 & 0.0 & 9 & 4.2 & 7 & 4.0 & $<0.01$ \\
\hline Tuberculosis co-infection & 13 & 6.3 & 10 & 4.6 & 18 & 9.8 & 0.12 \\
\hline
\end{tabular}




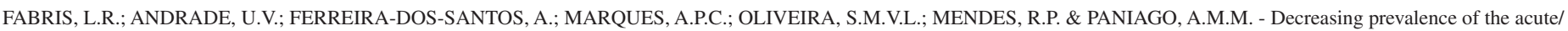
subacute clinical form of paracoccidioidomycosis in Mato Grosso do Sul State, Brazil. Rev. Inst. Med. Trop. Sao Paulo, 56(2): 121-5, 2014.

Table 2

Distribution of 595 paracoccidioidomycosis patients by period of admission at the service, clinical form and outcome

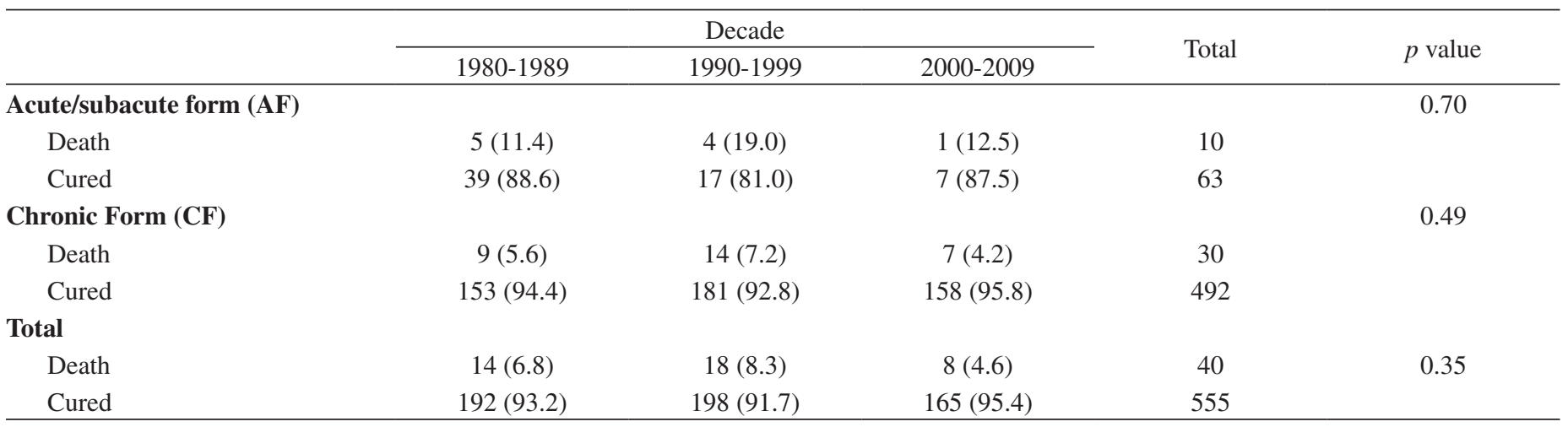

in the first decade, $90.0 \%$ in the second decade and $89.6 \%$ in the third decade.

\section{DISCUSSION}

The prevalence of different clinical forms of PCM varies depending on the geographic area in which it occurs. The acute-subacute form, also called the juvenile form, is less prevalent than the chronic form, or the adult form. However, PCM prevalence was higher in the states of Pará,

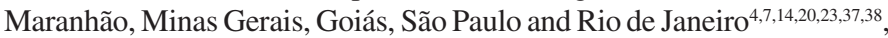
than observed in the state of Rio Grande do Sul and in neighboring countries like Argentina and Paraguay, where the disease occurs almost exclusively in adult men ${ }^{10,15,18,28}$.

These differences have not been explained and may be related to multiple factors. Deforestation in agricultural frontiers, such as occurs in the Amazon region in the states of Pará, Maranhão and Tocantins, could result in a greater risk of presenting the acute/subacute form due to an higher exposure rate to the inoculum and/or by reaching a population whose previous exposure to fungus never occurred or was uncommon. Occupational exposure of children and young adults to $P$. brasiliensis during farm work may be greater in these locations.

Furthermore, the discovery of differences between pathogenic strains of $P$. brasiliensis, which culminated in the description of a new species named Paracoccidioides lutzii ${ }^{35}$, could explain these clinical differences, which are still unknown for PCM but demonstrated in classical and African histoplasmosis and neoformans e gattii cryptococcosis ${ }^{33,34}$. Studies on the geographical distribution of $P$. lutzii are still preliminary ${ }^{36}$.

The reduction in acute/subacute cases observed during the study period may have been due to the significant increase in the age group affected by the disease related to the lower exposure of children and adolescents to the fungus as a result of intense public policy aimed at reducing child labor in the plantations of the country ${ }^{8}$.

The prevalence and incidence of the acute/subacute form also depends on environmental conditions. A cluster of this clinical form was observed in the region of Botucatu and was related to the El Niño Southern Oscillation (1982 - 1983). This climatic event increased the soil water storage with consequent production of conidia and increased moisture in the air in 1984, leading to this temporal cluster in $1985^{3}$. Interestingly, in this study, the prevalence of the acute/subacute form was higher during the period 1980 - 1989, the same decade in which the cluster was observed in the region of Botucatu (SP). If this explanation is applied to the findings of the State of Mato Grosso do Sul, the first decade of this study would have shown an increase in acute/subacute cases. Thus, a study of climatic variables and soil conditions could contribute to a more concrete explanation of the observed variation.

The prevalence of female cases also decreased. In the prepubertal age, PCM has been known to occur in similar proportions between boys and girls, with a gender ratio of 1.7:1.0 $0^{13}$. After menarche, women become less susceptible to PCM due to the presence of estrogen, which slows or inhibits the transformation of filamentous phase, the infective, pathogenic yeast phase ${ }^{31}$. In this way, the chronic form is much more prevalent in men, with a gender ratio of $15: 1^{24}$.

In this study, there were no cases of PCM co-infection with AIDS in the first decade, a period in which there occurred fewer AIDS cases in the state and AIDS was prevalent in homosexual men and/or residents of the most populous cities ${ }^{7}$. In the next two decades, the prevalence of this co-infection remained stable at $4.2 \%$ and $4.0 \%$, respectively.

Since $P$. brasiliensis is an intracellular parasite and resistance to PCM depends on cell mediated immunity, a significant increase of PCM associated with HIV infection was expected. This association has been observed less frequently than with other endemic systemic mycoses, such as histoplasmosis ${ }^{5,922,25}$. The usage of low doses of trimethoprimsulfamethoxazole for prophylaxis of Pneumocystis jirovecci by patients in the study population could be a possible explanation for the relatively low incidence of PCM-AIDS co-infection. This medicine would also have protected against $P$. brasiliensis infection.

Another possible explanation could be less exposure of HIV-infected patients, who generally live in urban areas, to $P$. brasiliensis, which is reserved in rural agricultural areas. A study of HIV-infected individuals ${ }^{29}$, in the same study center showed a $12.5 \%$ prevalence of $P$. brasiliensis infection by assessing intra-dermal reactions with gp43. The dosage used was $0.1 \mathrm{~mL}$ of gp43 at a concentration of $60 \mu \mathrm{L} / \mathrm{mL}$, which is the 
FABRIS, L.R.; ANDRADE, U.V.; FERREIRA-DOS-SANTOS, A.; MARQUES, A.P.C.; OLIVEIRA, S.M.V.L.; MENDES, R.P. \& PANIAGO, A.M.M. - Decreasing prevalence of the acute/ subacute clinical form of paracoccidioidomycosis in Mato Grosso do Sul State, Brazil. Rev. Inst. Med. Trop. Sao Paulo, 56(2): 121-5, 2014

same as used in other studies with non-HIV infected individual ${ }^{19}$. In that study, regarding the levels of CD4+ cells, $23.3 \%$ of patients presented less than 200 cells $/ \mathrm{mm}^{3}, 22.2 \%$ presented between 200 and 350 cells/ $\mathrm{mm}^{3}$, and $54.5 \%$ presented more than 350 cells $/ \mathrm{mm}^{3}$. The possible anergy of HIV-positive patients is important to consider, especially those with lower CD4+. No control group was used for comparison. However in the same region in a population of farm workers with no HIV-infected individuals, the prevalence was found to be $45.8 \%{ }^{19}$

PCM-tuberculosis coinfection has been observed in $5.5 \%$ to $19 \%$ of patients with this mycosis ${ }^{17,24,26}$ and constitutes an important public health issue, not only for the high prevalence of tuberculosis in Brazil, but also because they are involved in the differential diagnosis of many cases ${ }^{16}$.

Throughout the study period, $6.9 \%$ of PCM patients showed active pulmonary tuberculosis during the course of this mycosis. The prevalence of PCM-tuberculosis co-infection remained stable throughout the study period. Interestingly, tuberculosis is observed in poorly ventilated urban areas and PCM predominates in rural environments ${ }^{27}$. The migration of rural workers to urban areas is increasing, which could explain the increased exposure of the patient with PCM to Mycobacterium tuberculosis.

Data on the mortality of the disease are rare. Deaths by PCM have been observed in $4.3 \%$ to $14.0 \%$ of cases, and the most frequent cause of death of patients with the chronic form are respiratory failure and Addison's syndrome, while the acute/subacute cases are intensely disseminated and involve multiple organs ${ }^{1,2,37}$. In the present study, $6.7 \%$ of patients died, with no noticeable reduction in this rate from the first to the third decade. A potential explanation for this finding could be the difficulty of PCM treatment compliance observed in the study population $^{24}$.

Treatment was the same (cotrimoxazole) throughout the study period; however, the dosage and period of treatment could not be ascertained during the retrospective phase of the study (1980 to 1998).

For the same reason, other data, as such sequel and relapse rates and time between onset of symptoms and treatment initiation, could not be compared and was a limitation of the study design

The main change in the epidemiology of the disease observed over the three decades studied in Mato Grosso do Sul was the increased age of cases affected by paracoccidioidomycosis which was accompanied by a reduction in the prevalence of female cases and acute/subacute cases.

\section{RESUMO}

\section{Redução na prevalência da forma aguda/subaguda da paracoccidioidomicose em Mato Grosso do Sul, Brasil}

Com o objetivo de avaliar o comportamento da paracoccidioidomicose nas últimas três décadas, dados clínicos e epidemiológicos de 595 pacientes atendidos dentre 1980 a 2009 no Hospital da Universidade Federal de Mato Grosso do Sul foram estudados. Sexo, faixa etária, forma clínica, associação com tuberculose ou AIDS e mortalidade foram comparados por década em que a doença foi diagnosticada. Observou-se, nas três décadas do estudo, uma redução do percentual de mulheres, de pacientes do grupo de 20 a 39 anos, assim como de casos com a forma aguda/subaguda. Estas alterações estão intimamente relacionadas e podem ser analisadas simultaneamente. Houve aumento de casos de coinfecção com AIDS da primeira para segunda década, coincidindo com o surgimento da epidemia, e manteve-se estável durante a década seguinte. Não houve alteração da taxa de coinfecção com tuberculose, que no geral foi de $6,9 \%$ o que reforça a importância desta comorbidade. A taxa geral de mortalidade foi de $6,7 \%$ e também não variou entre as décadas estudadas. A manutenção da taxa de óbitos chama a atenção para a relevância dessa doença negligenciada.

\section{REFERENCES}

1. Andrade ALSS. Paracoccidioidomicose linfático-abdominal: contribuição ao seu estudo. Rev Patol Trop. 1983;12:165-256.

2. Azevedo JF, Lisboa CSG. Paracoccidioidomicose - estudo de 106 casos. J. Pneumol. $1980 ; 6: 30-3$

3. Barrozo LV, Benard G, Silva MES, Bagagli E, Marques SA, Mendes RP. First description of a cluster of acute/subacute paracoccidioidomycosis cases and its association with a climatic anomaly. Plos Negl Trop Dis. 2010;4(3):e 643.

4. Bellisimo-Rodrigues F, Machado AA, Martinez R. Paracoccidioidomycosis epidemiological features of a 1,000-cases series from a hyperendemic area on the Southeast of Brazil. Am J Trop Med Hyg. 2011;85:546-50.

5. Benard G, Duarte AJS. Paracoccidioidomycosis: a model for the evaluation of the effects of HIV infection in the natural history of endemic tropical diseases. Clin Infect Dis. 2002;31:1032-9

6. Blotta MHSL, Mamoni RL, Oliveira SJ, Noier SA, Papaiordanou PM, Goveia A. Endemic regions of paracoccidioidomycosis in Brazil: a clinical and epidemiologic study of 584 cases in the southeast region. Am J Trop Med Hyg. 1999;61:390-4.

7. Brasil. Boletim Epidemiológico AIDS. Julho a setembro de 2001. [Cited: 2012 Sept 05]. Available from: http://www.aids.gov.br/sites/default/files/Boletim Epidemiologico_2001_III_Aids_0.pdf

8. Brasil. Decreto Legislativo ${ }^{\circ} 178$, de 14 de dezembro de 1999 , e promulgada pelo Decreto no 3.597, de 12 de setembro de 2000. Estatuto da Criança e do Adolescente [Internet]. Ministério da Saúde. 2008 nov. 14 [Cited: 2012 Aug 15]. Available from: http://bvsms.saude.gov.br/bvs/publicacoes/estatuto_crianca_adolescente_3ed.pdf.

9. Chang MR, Taira CL, Paniago AMM, Taira DL, Cunha RV, Wanke B. Study of 30 cases of histoplasmosis observed in the Mato Grosso do Sul State, Brazil. Rev Inst Med Trop Sao Paulo. 2007;49:37-9.

10. Colares SM, Marcantônio S, Zambonato S, Severo LC. Acute/subacute disseminated paracoccidioidomycosis. First case in Rio Grande do Sul State, Brazil. Rev Soc Bras Med Trop. 1998;31:563-7.

11. Conti-Díaz IA, Callegari LF. Paracoccidioidomicosis en Uruguay: su estado y problematica actuales. Bol Of Sanit Panam. 1979;86:219-27.

12. Coutinho ZF, Silva D, Lazera M, Petri V, Oliveira RM, Sabroza PC, et al. Paracoccidioidomycosis mortality in Brazil. Cad Saúde Pública. 2002;18:1441-54.

13. Fonseca ERS, Pardal PPO, Severo LC. Paracoccidioidomicose em crianças em Belém do Pará. Rev Soc Bras Med Trop. 1999;32:31-3.

14. Franco M, Peraçoli MT, Soares A, Montenegro MR, Mendes RP, Meira DA. Hostparasite relationship in paracoccidioidomycosis. Curr Top Med Mycol. 1993;5:115-49.

15. Gimenez MM, Storni LP, Gimenez MF. Paracoccidioidomicosis. Nuestra experiencia. Rev Argent Dermatol. 1984;65:273-9. 


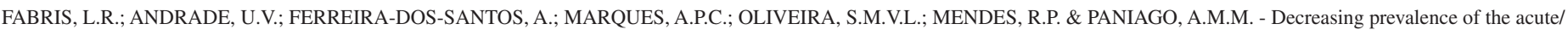
subacute clinical form of paracoccidioidomycosis in Mato Grosso do Sul State, Brazil. Rev. Inst. Med. Trop. Sao Paulo, 56(2): 121-5, 2014.

16. Hijjar MA, Oliveira MJPR, Teixeira GM. A tuberculose no Brasil e no mundo. Bol Pneumol Sanit. 2001;9(2):9-16.

17. Leão RC, Mendes E. Paracoccidioidomycosis, neoplasia and associated infections. Allergol Immunopathol (Madr). 1980;8:185-8.

18. Londero AT, Ramos CD. Paracoccidioidomicose. Estudo clínico e micológico de 260 casos observados no Estado do Rio Grande do Sul. J Pneumol. 1990;16:124-8.

19. Marques APC, Oliveira SMVL, Rezende GR, Melo DA, Fernandes-Fitts SM, Pontes ERJC, et al. Evaluation of Paracoccidioides brasiliensis infection by gp 43 intradermal test in rural settlements in Central-West Brazil. Mycopathologia. 2013,175:3-4.

20. Matos WB, Dos Santos GM, Silva VEB, Rosario Gonçalves EG, Silva AR. Paracoccidioidomycosis in the state of Maranhão, Brazil: geographical and clinical aspects. Rev Soc Bras Med Trop. 2012;45:385-9.

21. Mendes RP. The gamut of clinical manifestations. In: Franco M, Lacaz CS, RestrepoMoreno A, Del Negro G. Paracoccidioidomycosis. Boca Raton: CRC; 1994. p. 233-58.

22. Morejón KML, Machado AA, Martinez R. Paracoccidioidomycosis in patients infected with and not infected with human immunodeficiency virus: a case-control study. Am J Trop Med Hyg. 2009;80:359-66.

23. Nogueira MGS, Andrade GMQ, Tonelli E, Diniz SN, Goes AM, Cisalpino PS. Aspectos laboratoriais evolutivos de crianças em tratamento de paracoccidioidomicose. Rev Soc Bras Med Trop. 2006;39:478-83.

24. Paniago AMM, Aguiar JIA, Aguiar ESA, Cunha RV, Pereira GROL, Londero AT, et al. Paracoccidioidomicose: estudo clínico e epidemiológico de 422 casos observados no estado de Mato Grosso do Sul. Rev Soc Bras Med Trop. 2003;36:455-9.

25. Paniago AMM, Freitas ACC, Aguiar ASA, Aguiar JIA, Cunha RV, Castro ARCM, et al. Paracoccidioidomycosis in patients with human immunodeficiency virus: review of 12 cases observed in an endemic region in Brazil. J Infect. 2005;51:248-52.

26. Quagliato-Júnior R, Grangeia TAG, Massucio RAC, Capitani EM, Rezende SM, Balthazar AB. Association between paracoccidioidomycosis and tuberculosis: reality and misdiagnosis. J Bras Pneumol. 2007;33:295-300.

27. Rodrigues CC. Avaliação da infecção por Histoplasma capsulatum por meio de reações intra-dérmicas em moradores da zona urbana e rural do Município de Pratânia (SP). [tese]. Botucatu: Universidade Estadual Paulista, Faculdade de Medicina; 2004.
28. Rolon PA. Paracoccidioidomicosis - Epidemiologia en La República Del Paraguay, Centro Sud América. Mycopathologia. 1976;59:67-80.

29. Sarti ECFB, Oliveira SMVL, Santos LFS, Camargo ZP, Paniago AMM. Paracoccidioidal infection in HIV patients at an endemic area of paracoccidioidomycosis in Brazil Mycopathologia. 2012;73:145-9.

30. Severo LC, Geyer GR, Londero AT, Porto MS, Rizzon CFC. The primary pulmonary lymph node complex in paracoccidioidomycosis. Mycopathologia. 1979;67:115-8.

31. Shankar J, Restrepo A, Clemons KV, Stevens DA. Hormones and the resistance of women to paracoccidioidomycosis. Clin Microbiol Rev. 2011;24:296.

32. Shikanai-Yasuda MA, Telles Filho FQ, Mendes RP, Colombo AL, Moretti ML. Consenso em paracoccidioidomicose. Rev Soc Bras Med Trop. 2006;39:297-310.

33. Singh S, Kalra R, Chhabra S, Agarwal R, Garg S, Mathur SK. Variable clinical presentations of histoplasmosis: a report of six cases. Trop Doct. 2012;42:32-4.

34. Speed B, Dunt D. Clinical and host differences between infections with the two varieties of Cryptococcus neoformans. Clin Infect Dis. 1995;21:28-34.

35. Teixeira MM, Theodoro RC, Carvalho MJ, Fernandes L, Paes HC, Hahn RC, et al. Phylogenetic analysis reveals a high level of speciation in the Paracoccidioides genus. Mol Phylog Evolut. 2009;52:273-83.

36. Theodoro RC, Teixeira MM, Felipe MSS, Paduan KS, Ribolla PM, San-Blas G, et al Genus Paracoccidioides. Species recognition and biogeographic aspects. Plos One. 2012;7(5):e37694

37. Valle ACF, Wanke B, Wanke NCF, Peixoto TC, Perez M. Tratamento da paracoccidioidomicose: estudo retrospectivo de 500 casos: análise clínica, laboratorial e epidemiológica. An Bras Dermatol. 1992;67:251-4.

38. Veras KN. Paracoccidioidomicose. Estudo epidemiológico e clínico de pacientes internados no Hospital de Doenças Infecto-Contagiosas (HDIC) em Teresina, Piauí. Identificação de reserváreas nos Estados do Pará e Maranhão. [dissertação]. Rio de Janeiro: Fundação Oswaldo Cruz; 1995

Received: 28 January 2013

Accepted: 5 August 2013 